\title{
Somatic Embryogenesis of Neoglaziovia variegata (Arruda) Mez, an Important Source of Fiber from Native Brazilian Bromeliads
}

\author{
Daniela Garcia Silveira ${ }^{1 *}$, Lucimeire Souza Morais Lino ${ }^{2}$, Antônio da Silva Souza ${ }^{3}$ and \\ Fernanda Vidigal Duarte Souza ${ }^{3}$ \\ ${ }^{I}$ Instituto Federal Baiano; 46430-000; Guanambi - BA - Brasil. ${ }^{2}$ Embrapa; 44380-000; Cruz das Almas - BA - \\ Brasil. ${ }^{3}$ Embrapa Mandioca e Fruticultura; 44380-000; Cruz das Almas - BA - Brasil
}

\begin{abstract}
Neoglaziovia variegata (Arruda) Mez, a Bromeliad endemic to the Brazilian Caatinga and source of fiber for many different products, is considered an endangered species. Leaf and stem segments were cultivated on Murashige and Skoog (MS) medium with combinations of 2,4- dichlorophenoxyacetic acid (2,4-D) (0, 9, 18 and $27 \mu M)$ and glutamine $\left(0,50,100,150,200 \mathrm{mg} \mathrm{L}^{-1}\right)$ for the induction of embryogenic calli. Leaf segments did not present a favorable response for the combinations analyzed. The best response for embryogenic calli frequency with the best distribution of somatic embryos on the surface and better conversion rate was obtained using the stems explants in the medium containing $18 \mu \mathrm{M}$ 2,4-D and $100 \mathrm{mg} \mathrm{L}^{-1}$ glutamine. The embryogenic calli obtained from the different induction media were transferred to MS medium supplemented with 30 g.L $L^{-1}$ sucrose, 2.4 g. $L^{-1}$ Phytagel ${ }^{\circledR}, 0.53 \mu M$ $\alpha$-naphthalene acetic acid (NAA) and $0.88 \mu \mathrm{M}$ of 6-benzylaminopurine (BAP). The regenerated plants presented normal growth; however, many embryos did not fully develop.
\end{abstract}

Key words: Caroá, Bromeliaceae, tissue culture, 2,4-D, glutamine

\section{INTRODUCTION}

Neoglaziovia variegata (Arruda) Mez, popularly known as caroá, is an endemic Bromeliad from the Caatinga, which plays an important economic and social role in the Semi-arid Region of Northeast Brazil. Its fibers are used in the textile industry and fine craftsmanship, constituting a primary source of employment and income for many families in the Northeast (Ribeiro 2007; Silveira et al. 2009a). Furthermore, like other plants of the bromeliad family and due to the quality of the fiber, it can be used in the formulation of polymeric compounds for the development of many industrial products (Leão et al. 2009; Sena
Neto et al. 2013). This species has been used since the last century without any set cultivation system. Harvesting is carried out at large-scale using extractivism practices, drastically reducing the population of these plants in some regions. In addition, the increased devastation of the Caatinga for the development of agricultural activities has placed this species under endangered conditions. Therefore, there is a need of immediate studies to establish the strategies for genetic conservation and for the development of a cultivation system for this species (Silveira et al. 2009a). For both objectives, the basic requirement is the large-scale production of seedlings, associated with studies on

*Author for correspondence: danielags@ig.com.br 
its genetic variability as reported in previous studies (Silveira et al. 2009b).

As regards the conservation, a micropropagation protocol for in vitro germination of caroá plants has already been developed along with the results of the genetic variability studies of three distinct caroá populations (Silveira et al. 2009a).

Nevertheless, in order to grow this plant for use at an industrial level, such as in the case of reinforcement polymeric matrices, or even for fiber production to be used in craftsmanship, a very high number of seedlings in uniform conditions is necessary. Somatic embryogenesis is highly efficient as a massive propagation leading to high multiplication rates and to individual embryos that develop into complete plants (Ibaraki and Murata 2001), also helping germplasm conservation programs. There are many factors responsible for the success of the embryogenic process, from the appearance of the first embryos to the number of embryos produced per explant. Among these factors, the combination of regulators used in the induction stage, the duration of this stage, the origin of the explant and the physiological stage of the mother plant are important (Dublin 1991).

The type and concentration of the phytoregulators used varies according to the need for each species. Krikorian et al. (1987) reported that in the induction of the somatic embryogenic stage, the presence of 2,4-D (2,4 - dichlorophenoxyacetic acid) was crucial for cell proliferation. Another relevant factor for this stage of somatic embryogenesis is the addition of organic sources of nitrogen, because in some situations, they are fundamental for the formation of calli and somatic embryos (Kirby et al. 1987). Glutamine is often used in culture medium as a source of organic nitrogen (Frankilin and Dixon 1994). Many studies have shown that the use of this amino acid can be beneficial to in vitro cultivation, increasing the regeneration rate and explants biomass (Higashi et al. 1997; Dal Vesco and Guerra 2001; Vasudevan et al. 2004). In bromeliads, glutamine was an excellent source of nitrogen to increase the dry matter of aerial parts of plants grown in vitro besides strongly influencing both the hormonal content of buds (Mercier and Kerbauy 1998) and the process of direct organogenesis in leaves (Hamasaki et al. 2005).

In view of the above, this work aimed to study the effect of different explants and concentrations of 2,4-D and glutamine in the formation of embryogenic calli and regeneration of $N$. variegata plants.

\section{MATERIALS AND METHODS}

This work was carried out in three steps: (1) seed germination to obtain the seedlings to use as explants source; (2) the induction of somatic embryogenesis, and (3) the maturation and rooting of somatic embryos.

\section{Plant material and seed germination}

The seeds were collected from the mature and immature fruits from inflorescences collected from caroá plants originated from Valente county, a semiarid region of the Caatinga in Bahia where it grew naturally. (Geographic coordinates: $11^{\circ} 20^{\prime} 27,5^{\prime \prime} \mathrm{S}$ and $39^{\circ} 27^{\prime} 33,2^{\prime \prime} \mathrm{W}$, altitude: $376 \mathrm{~m}$ ). Initially, the seeds were washed in water and a commercial detergent (10 drops/l) and rinsed three times with distilled water. The disinfestation procedure was carried out under aseptic conditions in a laminar flow hood sterilized with ethanol (70\%) for 5 minutes and, afterwards, in a 1:1 solution of commercial bleach $(2 \%$ active chloride) with deionized water for 20 minutes. After the treatment with bleach, three consecutive washes with autoclaved distilled water were carried out. For the seed inoculation, test tubes (25 x $150 \mathrm{~mm}$ ) containing $15 \mathrm{~mL}$ MS medium (Murashige and Skoog 1962), supplemented with 30 g.L $L^{-1}$ sucrose, solidified with 2 g.L . $^{-1}$ Phytagel ${ }^{\circledR}$, $\mathrm{pH}$ adjusted to 5.8 and autoclaved at $120^{\circ} \mathrm{C}$ for 20 minutes, were used. The seeds were kept under a $16 \mathrm{~h}$ photoperiod with photon flow density of $22 \mu \mathrm{E} \cdot \mathrm{m}^{-2} \cdot \mathrm{s}^{-1}$ in the growth chambers with controlled temperature $\left(27 \pm 1^{\circ} \mathrm{C}\right)$ for 60 days. The seedlings were obtained and transferred to MS medium, supplemented with $0.53 \mu \mathrm{M}$ NAA $(\alpha-$ naphthalene acetic acid), 4.4 $\mu \mathrm{M}$ BAP (6benzylaminopurine), 30 g. $\mathrm{L}^{-1}$ of sucrose and 2.4 g. $\mathrm{L}^{-1}$ Phytagel $^{\circledR}$, where they remained for six weeks until the explants were ready to set up the experiment. The $\mathrm{pH}$ of the medium and the growth conditions were the same as described above.

\section{Induction of somatic embryogenesis}

Leaf segments longitudinally cut into $0.8 \mathrm{~mm}$ pieces and transversal cuts of the stem were transferred to Petri dishes $(100 \times 20 \mathrm{~mm})$ with 40 mL MS medium, 30 g.L. $\mathrm{L}^{-1}$ sucrose, 7 g.L $\mathrm{L}^{-1}$ agar, supplemented with $5.7 \mu \mathrm{M}$ Indole-3-acetic acid 
(IAA), $5.3 \mu \mathrm{M}$ NAA and with all the combinations between the concentrations of 2,4-D $(0,9,18$ and $27 \mu \mathrm{M})$ and glutamine $(0,50,100,150$ e $200 \mathrm{mg}$ $\mathrm{L}^{-1}$ ), with $\mathrm{pH}$ adjusted to 5.8. The experimental design was a complete randomized block in a $2 \times 4$ x 5 factorial scheme with two types of explants, four concentrations of 2,4-D and five concentrations of glutamine. Each treatment had 10 replicates that consisting of a Petri dish containing six segments from a single leaf and five segments of the stem explant. The explants were kept in a dark room at $27^{\circ} \mathrm{C}$. In order to monitor the development of the explants periodic evaluations were performed in interval periods of 15 days. After 60 days of cultivation, the frequency of explants with shoot formation (\%) and with embryogenic callus (\%) was recorded. The number and position of embryogenic callus on the explants were registered according the following scale: 1 - callus with the embryos in $1 / 4$ of its surface; 2 - callus presenting the embryos in $1 / 2$ of its surface, and 3-callus presenting the embryos on its entire surface. The number of embryogenic calli with embryos in different stages of histodifferentiation, was also recorded. The analyses of variance were carried out and for the frequency analyses, data were transformed to $(\mathrm{x}+$ $0.5)^{0.5}$. The means were compared by the Tukey's test at 5\% of probability and the SAS statistical software system (SAS Institute Inc 2004) was used.

\section{Maturation and rooting}

Calli fragments with somatic embryos were separated and transferred to MS medium supplemented with 30 g. $\mathrm{L}^{-1}$ sucrose, 2.4 g.L. ${ }^{-1}$ Phytagel $^{\circledR}, 0.53 \mu \mathrm{M}$ NAA and $0.88 \mu \mathrm{M}$ BAP
(Silveira et al. 2009b) and cultivated under a $16 \mathrm{~h}$ photoperiod with photon flow density of $22 \mu \mathrm{E} . \mathrm{m}$ ${ }^{2} . \mathrm{s}^{-1}$ and temperature of $27 \pm 1^{\circ} \mathrm{C}$ during four weeks for embryo maturation. After complete development of the embryos, the plants were transferred to MS hormone-free medium for embryo germination. The number of embryos converted into plants per calli fragments was registered.

\section{RESULTS AND DISCUSSION}

Results regarding the leaf explants were negligible, at least for the conditions established in this study with lack of callogenesis in most treatments. Just one treatment, $18 \mu \mathrm{M}$ 2,4-D and $100 \mathrm{mg} . \mathrm{L}^{-1}$ glutamine, had a frequency of $0.6 \%$ with globular embryos reported at the base of the leaf, as shown in Figure 1A. Most leaf explants had a brownish color (Fig. 1B), not showing any growth, suggesting necrosis. On the other hand, in this type of explant, the growth of friable nonembryogenic calli, with loosely tight cells and translucid white color, resembling cell nodulations, was reported. The formation of this type of callus was favored in the treatment with 27 $\mu \mathrm{M}$ 2,4-D and $50 \mathrm{mg} . \mathrm{L}^{-1}$ of glutamine (data not shown); however, embryos, or plants were not formed. Silva et al (2009) reported good results with the addition of $\mathrm{NH}_{4} \mathrm{NO}_{3}$ to the culture medium with shoot formation at the leaf base. In Dyckia maritime Baker similar results were obtained, where the higher levels of $\mathrm{NH}_{4} \mathrm{NO}_{3}$ concentration on the culture medium increased the multiplication rate (Da Silva et al. 2005).
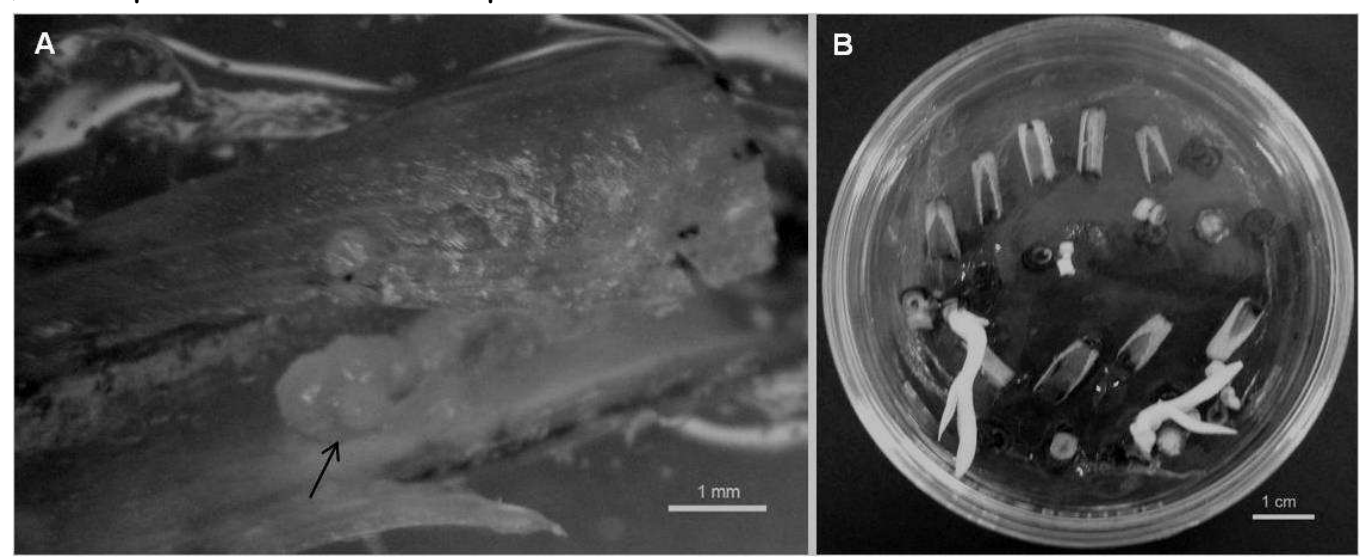

Figure 1 - Globular embryo formation close to the base of the leaf (A) and leaf explants without development showing brownish color and shoots originated from fragments stems explants by direct organogenesis (B). 
According to these authors, the $\mathrm{NH}_{4} \mathrm{NO}_{3}$ concentrations could influence the endogenous levels of plant growth regulators, as demonstrated with other bromeliads (Mercier and Kerbauy 1998) and could be an interesting strategy to use in future work with Neoglaziovia variegata.

Two types of growth were reported in the explants from stem segments: plants formed directly from the base of the stem and embryogenic calli formed on the surface. The formation of the plants from direct organogenesis occurred in the treatment lacking 2,4-D, while the gain in competence increased significantly with the increase in the concentration of glutamine, showing the strong effect of this amino acid in this process with $57.5 \%$ explants converted into plants in the medium supplemented with $200 \mathrm{mg} . \mathrm{L}^{-1}$ glutamine (Fig. 2). The regenerative potential of the basal part of bromeliad leaves has already been described by Hosoki and Asahira (1980), in agreement with several previous studies (Firoozabady and Moy 2004; Hamasaki et al. 2005; Droste et al. 2005; Alves et al. 2006; Silva et al. 2009; Silva et al. 2012), but there were no reports on the use of stem explants. Actually, in vitro bromeliad plants form a false stem, which is formed by the base of the leaves joined together at the adjacency of the root system, since they are monocotyledons. This could explain the results obtained in this study. The influence of the type of explant in the success of an embryogenic protocol has been reported in the literature, although different responses can be related as species dependent (Magalhães et al. 2006; Dal Vesco and Guerra 2010). Successful results with leaf explants in pineapple, another bromeliad, were reported by several authors (Soneji et al. 2002; Sripaoraya et al. 2003; Firoozabady and Moy 2004), although they were not in agreement with the results of the present work.

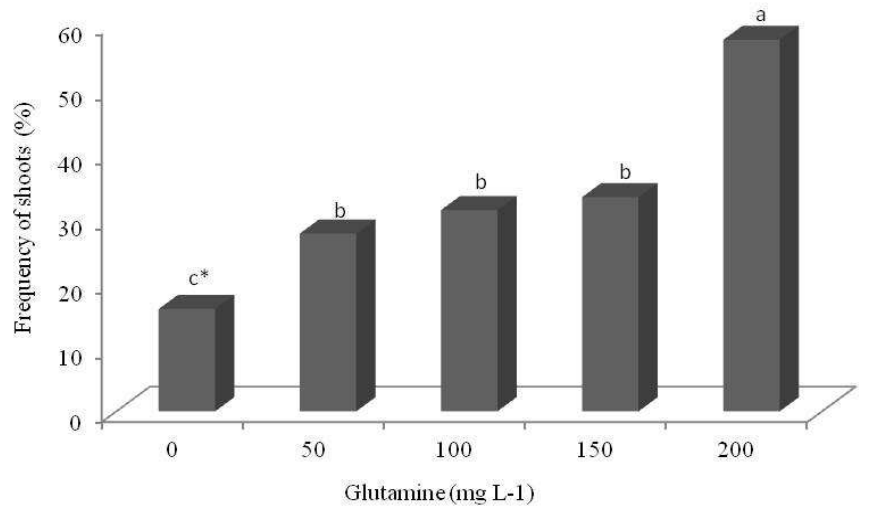

Figure 2 - Frequency of shoots $(\%)$ formed from stem segments after 60 days in culture medium without 2,4-D and with different concentrations of glutamine. *Averages followed by the same letters did not share significant differences at $5 \%$ probability by Tukey's test.

As regards the embryogenesis, the presence of 2,4$\mathrm{D}$ in the culture medium was crucial for the induction of embryogenic calli and the most promising results were reported using the explants from stem segments, showing growth after 40 days of culture. The embryogenic calli had a compact, granular aspect with whitish color. The evaluation carried out 60 days after in vitro culture started showed different responses regarding the combinations of the concentrations of 2,4-D and glutamine added to the culture medium. The frequency of explants with embryogenic calli was influenced by the presence of 2,4-D and glutamine in the culture medium; however, there was no significant interaction between them (Table 1).
The concentration of $18 \mu \mathrm{M}$ 2,4-D had the best result with a frequency of $52.8 \%$ embryogenic calli, whereas an inhibitory effect was observed with the concentration of $27 \mu \mathrm{M}$.

Results on glutamine showed that the addition of $100 \mathrm{mg} . \mathrm{L}^{-1}$ to the culture medium (fragments stems) during the initial stage of the process did not promote better results than the control treatment, whereas the highest concentrations ( 150 and $200 \mathrm{mg} \cdot \mathrm{L}^{-1}$ ) had a negative effect in the formation of embryogenic calli (Table 1). The addition of amino acids to the culture medium may inhibit, or promote the development of somatic embryogenesis and the response to these amino acids varies with the species and type of explant 
(George 1993; Khalil et al. 2002). For bromeliads, these responses are variable even though very high concentrations have shown an inhibitory effect in several studies. Hamasaki et al. (2005), studying with explants from the base of leaves of Ananas comosus var. Smooth Cayenne, obtained satisfactory results when 1 g.L $\mathrm{L}^{-1}$ glutamine was added to the shoot induction medium, despite the fact that at higher concentrations ( 2 and 4 g.. $\left.{ }^{-1}\right)$, the effect of glutamine for this organogenic process was reduced. The authors also noticed that the positive influence of glutamine in this process was due to the alterations in the endogenous concentrations of IAA and iP (6-(gamma,gamma- dimethylallylamino) purine) in the base of pineapple leaves. Dal Vesco and Guerra (2001), stuying A. sellowiana, noticed a significant increase in the percentage of induction of somatic embryogenesis when the culture medium was supplemented with glutamine, asparagine and arginine amino acids.

In regard to the distribution of embryos on the surface of the explant, the treatment with the combination of $18 \mu \mathrm{M}$ 2,4-D and $100 \mathrm{mg} \cdot \mathrm{L}^{-1}$ of glutamine promoted the highest frequency of calli with embryos, with emphasis to the calli which had embryos on the entire surface (Fig. 3A and Table 2).

Table 1 - Frequency (\%) of embryogenic calli formed from fragments stems explants after 60 days in culture medium with different concentrations of 2,4-D and glutamine.

\begin{tabular}{cc}
\hline $\mathbf{2 , 4 - D}(\boldsymbol{\mu M})$ & Frequency (\%) \\
\hline 0 & $0.00 \mathrm{c}^{*}$ \\
9 & $28.94 \mathrm{~b}$ \\
18 & $52.80 \mathrm{a}$ \\
27 & $35.35 \mathrm{~b}$ \\
\hline Glutamine $\left(\mathbf{m g . \mathbf { L } ^ { - 1 } )}\right.$ & Frequency (\%) \\
\hline 0 & $36.21 \mathrm{ab}$ \\
100 & $22.29 \mathrm{bc}$ \\
150 & $44.64 \mathrm{a}$ \\
200 & $24.04 \mathrm{bc}$ \\
\hline $\mathrm{CV}(\%)$ & $19.18 \mathrm{c}$ \\
\hline
\end{tabular}

*Means followed by the same letter do not differ significantly between themselves by the Tukey test at 5\% probability.

Table 2 - Number of embryogenic calli originated from fragments stems explants showing the distribution (position) of the somatic embryos in the calli after 60 days in culture medium considering all the combinations between the concentrations of 2,4-D and glutamine.

\begin{tabular}{ccccc}
\hline $\begin{array}{c}\text { Glutamine } \\
\left(\mathbf{m g ~ L ~ L ~}^{\mathbf{1}}\right)\end{array}$ & $\mathbf{2 , 4 - D}(\boldsymbol{\mu M})$ & $\begin{array}{c}\text { Embryos in } \mathbf{1 / 4} \text { of the } \\
\text { callus }\end{array}$ & $\begin{array}{c}\text { Embryogenic calli } \\
\text { Embryos on } \mathbf{1} \mathbf{2} \text { of the } \\
\text { callus }\end{array}$ & $\begin{array}{c}\text { Embryos in the entire } \\
\text { callus }\end{array}$ \\
\hline 0 & 0 & 0 & 0 & 0 \\
& 9 & 11 & 0 & 0 \\
& 18 & 11 & 11 & 1 \\
50 & 27 & 14 & 4 & 0 \\
& 0 & 0 & 0 & 1 \\
& 9 & 4 & 7 & 0 \\
100 & 18 & 10 & 2 & 0 \\
& 27 & 5 & 2 & 0 \\
& 0 & 0 & 0 & 2 \\
& 9 & 15 & 3 & 0 \\
150 & 13 & 10 & 15 & 0 \\
& 27 & 0 & 0 & 1 \\
& 0 & 3 & 1 & 0 \\
& 9 & 15 & 6 & 0 \\
& 18 & 8 & 8 & 0 \\
& 27 & 0 & 0 & 0 \\
& 0 & 6 & 0 & 0 \\
\end{tabular}


After 60 days of culture in the induction medium with different combinations of 2,4-D and glutamine, many calli had embryos in the proembryo and globular stages and few calli had embryos in the torpedo stage (Table 3). The development in non-synchronized fashion was observed, in which some calli presented embryos in different stages of histodifferentiation, mainly in the globular and torpedo stages (Fig. 3B). Nevertheless, no embryo in the cotyledonous stage was observed in any of the treatments, which presented embryogenic calli, which did not prevent these embryos from developing into whole plants afterwards. The culture medium used promoted the maturation and normal embryo development. According to the results presented on Table 3, the treatment with the combination of $18 \mu \mathrm{M}$ 2,4-D and $100 \mathrm{mg} . \mathrm{L}^{-1}$ glutamine was the one which showed the highest development of embryos in all stages of development.

Table 3 - Number of embryogenic calli originated from fragments stems explants with somatic embryos in different histodifferenciation stages cultured in medium with different concentrations of 2,4-D and glutamine after 60 days of induction.

\begin{tabular}{|c|c|c|c|c|c|}
\hline \multicolumn{2}{|c|}{ Treatment } & \multicolumn{4}{|c|}{ Embryogenic calli } \\
\hline $\begin{array}{l}\text { Glutamine } \\
\left(\mathrm{mg}^{\prime} \mathrm{L}^{-1}\right)\end{array}$ & $\begin{array}{l}\text { 2,4-D } \\
(\mu \mathrm{M})\end{array}$ & Pro-embryo & $\begin{array}{l}\text { Globular } \\
\text { Embryo }\end{array}$ & $\begin{array}{l}\text { Torpedo } \\
\text { Embryo } \\
\end{array}$ & $\begin{array}{c}\text { Globular + } \\
\text { Torpedo }\end{array}$ \\
\hline \multirow[t]{4}{*}{0} & 0 & 0 & 0 & 0 & 0 \\
\hline & 9 & 10 & 1 & 0 & 0 \\
\hline & 18 & 3 & 18 & 2 & 0 \\
\hline & 27 & 8 & 8 & 0 & 3 \\
\hline \multirow[t]{4}{*}{50} & 0 & 0 & 0 & 0 & 0 \\
\hline & 9 & 6 & 2 & 3 & 0 \\
\hline & 18 & 5 & 5 & 2 & 0 \\
\hline & 27 & 5 & 2 & 0 & 0 \\
\hline \multirow[t]{4}{*}{100} & 0 & 0 & 0 & 0 & 0 \\
\hline & 9 & 14 & 3 & 3 & 0 \\
\hline & 18 & 7 & 24 & 1 & 5 \\
\hline & 27 & 4 & 11 & 1 & 4 \\
\hline \multirow[t]{4}{*}{150} & 0 & 0 & 0 & 0 & 0 \\
\hline & 9 & 3 & 1 & 1 & 0 \\
\hline & 18 & 12 & 6 & 0 & 3 \\
\hline & 27 & 7 & 7 & 0 & 2 \\
\hline \multirow[t]{4}{*}{200} & 0 & 0 & 0 & 0 & 0 \\
\hline & 9 & 4 & 2 & 0 & 0 \\
\hline & 18 & 8 & 7 & 1 & 1 \\
\hline & 27 & 5 & 4 & 0 & 2 \\
\hline
\end{tabular}

Calli fragments with embryos cultured in the maturation medium showed different responses (Fig. 3C). During the 40 days of culture, not all the embryos were converted into plants with the development of root and stem apical meristems (Fig. 3D), whereas the embryos originated from the medium with $18 \mu \mathrm{M} 2,4-\mathrm{D}$ and $100 \mathrm{mg} . \mathrm{L}^{-1}$ glutamine had the highest number of embryos converted into plants (Table 4), probably due to the highest number of embryos in the most advanced stages of development. These plants were transferred to the embryo germination medium and developed normally (Fig. 3E and F). Table 4 showed that glutamine that did not have any significant effect in the embryo induction stage, nevertheless it played an important role in the conversion of embryos into plants. Also, embryos with morphological changes were reported, especially, cotyledon fusion and embryos that did not form plants.

These results might be due to the long period in which the embryos were maintained in the medium containing 2,4-D during the induction stage. Several reports in the literature mention the occurrence of anomalous embryos, probably due to long periods of exposure to the auxin 2,4-D, which may lead to physiologic or genetic alterations (Guerra et al. 1999; Pescador et al. 2008). Therefore, in view of the results, the reduction in the concentrations of these regulators as well as the time of exposure should be reevaluated. Other resources for embryogenesis induction, such as temperature stresses are being tested in some species and may be an alternative to 
avoid high rates of not well-formed embryos. This is the first report in search of a somatic embryogenesis protocol in caroá which could provide important information to the future breeding program of this species considered endangered in the Brazilian Caatinga. The results could be promising and showed the viability of the use of this technique in multiplication and conservation programs of the $N$. variegata species.
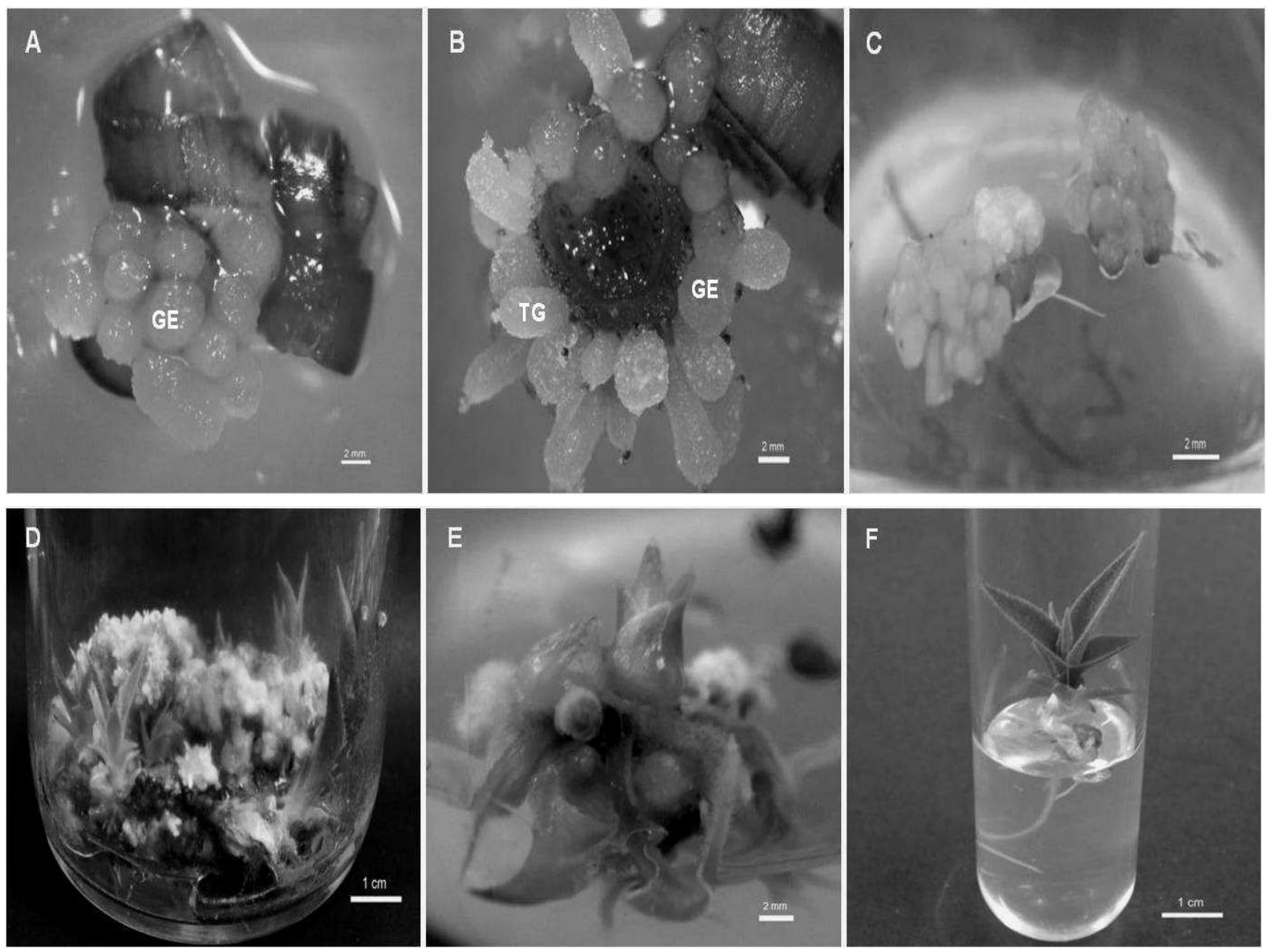

Figure 3 - Somatic embryogenesis in caroá [Neoglaziovia variegata (Arruda) Mez]. (A) fragments stems with globular embryos (GE) distributed on the entire surface after 60 days in culture medium; (B) embryos in the globular and torpedo (TE) stages in the fragments stems after 60 days in culture medium; (C) calli with embryos cultured in the maturation medium; (D) regeneration of embryos into plants and embryos without development (anomalous); (E) view of a plant regenerated from somatic embryo; $(F)$ single caroá plant in MS medium free of plant growth regulators. 
Table 4 - Number of embryos converted into plants from fragments of Neoglaziovia variegata stems in the different treatments.

\begin{tabular}{ccc}
\hline & Treatment & Number of plants \\
\hline Glutamine $\left(\mathbf{m g . \mathbf { L } ^ { - 1 } )}\right.$ & $\mathbf{2 , 4 - D}(\boldsymbol{\mu M})$ & 6 \\
& 9 & 26 \\
& 18 & 15 \\
50 & 27 & 7 \\
& 9 & 10 \\
100 & 18 & 9 \\
& 27 & 8 \\
& 9 & 42 \\
150 & 18 & 20 \\
& 27 & 4 \\
200 & 9 & 24 \\
& 18 & 12 \\
& 27 & 4 \\
& 9 & 23 \\
& 18 & 11 \\
\hline
\end{tabular}

\section{CONCLUSIONS}

From the resulta, it was concluded that:

- The caroá leaf explants did not show embryogenic potential under the conditions of this report;

- The auxin 2,4-D was crucial for inducing embryogenic capacity;

- The use of $100 \mathrm{mg} \cdot \mathrm{L}^{-1}$ glutamine was essential for promoting the conversion of embryos into plants;

- The highest frequency of embryogenic calli and the best rates of conversion into plants were from the stem segment explants in medium supplemented with $18 \mu \mathrm{M}$ 2,4-D and $100 \mathrm{mg} \cdot \mathrm{L}^{-1}$ glutamine.

\section{REFERENCES}

Alves GM, Dal Vesco LL, Guerra MP. Micropropagation of the Brazilian endemic bromeliad Vriesea reitzii trough nodule clusters culture. Sci Hort. 2006; 110:204-7.

Dal Vesco LL, Guerra MP. The effectiveness of nitrogen sources in feijoa somatic embryogenesis. Plant Cell Tiss Org Cult. 2001; 64:19-25.

Dal Vesco LL, Guerra MP. In vitro morphogenesis and adventitious shoot mass regeneration of Vriesea reitzii from nodular cultures. Sci Hort. 2010; 125:748-755.
Da Silva ALL, Franco ETH, Bisognin DA, Dornelles EB, Walter JM. Efeitos do nitrato de amônia na multiplicação e regeneração de gemas laterais de Dyckia maritima Baker - Bromeliaceae. $R$ Bras Agrociência. 2005; 11(3):369-371.

Droste A, Silva AM, Matos AV, Almeida JW. In vitro culture of Vriesea gigantea and Vriesea philippocoburgii: Two vulnerable bromeliads native to southern Brazil. Braz, Arch Biol Technol. 2005. 48(5):717-722.

Dublin P. Multiplicación vegetativa de café, hevea e cacao. In: Roca WM, Mroginski LA (eds). Cultivo de tejidos en la agricultura; fundamentos y aplicaciones. Cali: CIAT; 1991. p. 612-642.

Firoozabady E, Moy Y. Regeneration of pineapple plants via somatic embryogenesis and organogenesis. In vitro Cell Dev Biol- Plant. 2004; 40:67-74.

Franklin CI, Dixon RA. Initiation and maintenance of callus and cell suspension cultures. In: Dixon RA, Gonzales RA (eds). Plant cell culture - a practical approach. New York: Oxford University Press; 1994. p. $1-25$.

Garin E, Bernier-Cardou M, Isabel N, Klimaszewska K, Plourde A. Effect of sugars, amino acids, and culture technique on maturation of somatic embryos of Pinus strobus on medium with two gellan gum concentrations. Plant Cell Tiss Org Cult. 2000; 62:27-37.

George EF. Plant propagation by Tissue culture. Parte 1 The Technology. Exegetics Edington, England;1993.

Guerra MP, Torres A C, Teixeira JB. Embriogênese somática e sementes sintéticas. In: Torres AC, Caldas LS, Buso, JA (eds). Cultura de tecidos e transformação genética de plantas, vol 2. Brasília: Embrapa-SPI; Embrapa-CNPH; 1999. p. 533-568. 
Hamasaki RM, Purgatto E, Mercier H. Glutamine enhances competence for organogenesis in pineapple leaves cultivated in vitro. Braz J Plant Physiol. 2005; 17(4):383-389.

Higashi K, Kamada H, Harada $H$. The effects of reduced nitrogenous compounds suggests that glutamine synthetase activity is involved in the development of somatic embryos in carrot. Plant Cell Tisss Org Cult. 1997; 45:109-114.

Hosoki T, Asahira T. In vitro propagation of bromeliads in liquid culture. HortScienc. 1980; 15: 603-604.

Ibaraki Y, Murata K. Automation of somatic embryo production. Plant Cell Tiss Org Cult. 2001; 65:179199.

Khalil SM, Cheah KT, Perez·EA, Gaskill DA, Hu JS. Regeneration of banana (Musa spp. AAB cv. Dwarf Brazilian) via secondary somatic embryogenesis. Plant Cell Rep. 2002; 20:1128-1134.

Kirby EG, Leustek T, Lee MS. Nitrogen Nutrition. In: Bonga JM, Durzan DJ (eds). Cell and tissue culture in forestry, vol 1. Dordrecht: Canadian Forestry Service and University of California; 1987. p. 67-88.

Krikorian AD, Kelly K, Smith DL. Hormones in tissue culture and micropropagation. In: Davies PJ (ed). Plant hormones and their role in plant growth and development. Dordrecht: Kluwer Academic Publishers; 1987. p. 593-613.

Leão AL, Machado IS, Souza SF, Soriano L. Production of curaua fibers for industrial applications: characterization and micropropagation. Acta Hortic. 2009; 822: 227-238.

Magalhães JS, Santos MDM, Cunha Filho FN, Blumer L, Guerra MP, Torres AC. Indução de embriogênese somática em genótipos de batata-doce. Hortic Bras. 2006; 24:79-83.

Mercier H, Kerbauy GB. Endogenous IAA and cytokinin levels in bromeliad shoots as influenced by glutamine and ammonium nitrate treatments. Rev Bras Fisiol Veg. 1998; 10:225-228.

Merkle SA, Parrott WA, Flinn BS. Morphogenic aspects of somatic. In: Thorpe TA (ed). In vitro embryogenesis in plant. Dordrecht: Kluwer Academic Publishers; 1995, p. 155-203.

Murashige T, Skoog FM. A revised medium for rapid growth and biossays with tobacco tissue cultures. Physiol Plant. 1962; 15:473-497.

Ogita S, Sasamoto H, Yeung EC, Thorpe TA. The effects of glutamine on the maintenance of embryogenic cultures of Cryptomeria japonica. In vitro Cell Dev Biol-Plant. 2001; 37:268-273.

Pescador R, Kerbauy GB, Viviani D, Kraus JE. Anomalous somatic embryos in Acca sellowiana (O.
Berg) Burret (Myrtaceae). Rev Bras Bot. 2008; 31:155-164.

Ribeiro M.B. Fibrocultura: o Semi Árido é o paraíso das fibras vegetais. In: Ribeiro MB (ed). A potencialidade do semi-árido brasileiro. Brasília: Revan; 2007, p. 121-136.

Sena Neto AR, Araujo MAM, Souza FVD, Mattoso LHC, Marconcini JM. Characterization and comparative evaluation of thermal, structural, chemical, mechanical and morphological properties of six pineapple leaf fiber varieties for use in composites. Ind Crops Prod. 2013; 43:529-537.

Shetty K, Asano Y, Oosaka K. Stimulation of in vitro shoot organogenesis in Glycine $\max$ (Merrill.) by allantoin and amides. Plant Sci. 1992; 81:245-251.

Silva ALL, Franco ETH, Dornelles EB, Reichert Bortoli CL, Quoirin M. In vitro multiplication of Vriesia scalaris E. Morrem (Bromeliaceae). Iheringia Sér Bot. 2009; 64:151-156.

Silva ALL, Costa JL, Alcantara GB, Carvalho DC, Schuck MR, Biasi LA, Scheidt GN, Soccol CR. Micropropagation of Nidularium innocentii Lem. and Nidularium procerum Lindm. (Bromeliaceae). Pak J Bot. 2012; 44:1095-1101.

Silveira DG, Amorim EP, Jesus ON, Souza FVD, Pestana KN, Santos VJ, Santana JRF. Variabilidade genética de populações naturais de caroá por meio de marcadores RAPD. Pesq Agropec Bras. 2009a;44:283-290.

Silveira DG, Souza FVD, Pelaccani CR, Souza AS, Ledo CAS, Santana JRF. Micropropagation and in vitro conservation of Neoglaziovia variegata (Arr. Cam.) Mez, a fiber producted bromeliad from Brazil. Braz Arch Biol Technol. 2009b; 52:923-932.

Soneji JR, Rao PS, Mhatre M. In vitro Regeneration from Leaf Explants of Pineapple (Ananas comosus L, Merr). J Plant Bioch Biotechnol. 2002; 11:117-9.

Sripaoraya S, Marchant R, Power JB, Davey MR. Plant regeneration by somatic embryogenesis and organogenesis in commercial pineapple (Ananas comosus L.). In vitro Cell Dev Biol- Plant. 2003; 39:450-454.

Vasudevan A, Selvaraj N, Ganapathi A, Kasthurirengan S, Ramesh Anbazhagan V, Manickavasagam M. Glutamine: a suitable nitrogen source for enhanced shoot multiplication in Cucumis sativus L. Biol Plant. 2004; 48:125-128. 
